\section{Advertising of Antibiotics}

SIR,-We would like to comment on certain aspects of the correspondence which has followed the publication of our letter on this subject (14 April, p. 116), particularly with reference to amoxycillin and cephradine.

We agree with Dr. E. T. Knudsen (28 April, p. 240) that changing a molecule in a compound may alter its action, but this is by no means invariable. For example, the May 1973 issue of MIMS contains 40 preparations of tetracycline and its derivatives which have different formulae but virtually identical antibacterial spectra.

We are not opposed to amoxycillin which, as Dr. Knudsen pointed out, is superior to ampicillin, and indeed it has been suggested that amoxycillin may shortly replace ampicillin in therapy. ${ }^{1}$ May and Ingold $^{2}$ consider it better than ampicillin in chest infections, and in our own small series of women with bacteriuria amoxycillin produced better results than we had previously obtained with ampicillin. ${ }^{3}$ Amoxycillin does have different pharmacological properties from ampicillin, but emphasizing the differences and ignoring the points of similarity only confuses the prescriber. All doctors are aware of the indications and side effects of ampicillin, and if they had been told that amoxycillin has an almost identical antibacterial spectrum to that of ampicillin, but was twice as well absorbed, they would have been fully informed as to its place in the treatment of patients suffering from infections.

Professor L. P. Garrod (28 April, p. 239) was right in saying that "a new orally administered cephalosporin must stand or fall by comparison with the only other such compound available in this country-namely, cephalexin." We have obtained a sample of cephradine by courtesy of Smith, Kline, and French Ltd., and some comparative sensitivities for cephradine and cephalexin are illustrated in the accompanying table. The antibacterial activity of the two compounds was almost identical for the organisms tested-staphylococci and various Gram-negative bacilli. There may, of counse, be pharmacological or toxicological differences between the two compounds which have not yet been elucidated. Meanwhile, there are now four oral cephalosporin preparations with similar antibacterial spectra: Ceporex and Keflex (both cepha-

Comparison of Sensitivity of Organisms to Cephradine (C1) and Cephalexin (C2)

\begin{tabular}{|c|c|c|c|c|c|c|c|c|c|}
\hline \multirow{2}{*}{ Organism } & \multirow{2}{*}{$\begin{array}{l}\text { Strains } \\
\text { Tested }\end{array}$} & \multicolumn{8}{|c|}{ Minimum Inhibitory Concentrations $(\mu \mathrm{g} / \mathrm{ml})$} \\
\hline & & 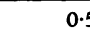 & 1 & 2 & 4 & 8 & 16 & 32 & $>32$ \\
\hline $\begin{array}{l}\text { Staphylococcus } \\
\text { pyogenes }\end{array}$ & 50 & $\begin{array}{l}\mathrm{C} 1 \\
\mathrm{C} 2\end{array}$ & $\begin{array}{l}4 \\
5\end{array}$ & $\begin{array}{l}14 \\
19\end{array}$ & $\begin{array}{l}13 \\
10\end{array}$ & $\begin{array}{l}6 \\
5\end{array}$ & -2 & $\begin{array}{l}4 \\
7\end{array}$ & $\begin{array}{l}7 \\
4\end{array}$ \\
\hline Staph. albus & 25 & $\begin{array}{ll}\mathrm{C} 1 & 1 \\
\mathrm{C} 2 & \end{array}$ & $\begin{array}{r}6 \\
10 \\
\end{array}$ & $\begin{array}{r}10 \\
7\end{array}$ & $\begin{array}{l}4 \\
5\end{array}$ & $\begin{array}{l}2 \\
1\end{array}$ & 2 & & \\
\hline Proteus spp. & 63 & $\begin{array}{l}\mathrm{C} 1 \\
\mathrm{C} 2\end{array}$ & 12 & 1 & $\begin{array}{l}3 \\
1\end{array}$ & $\begin{array}{l}21 \\
36\end{array}$ & $\begin{array}{r}16 \\
8\end{array}$ & $\frac{1}{2}$ & $\begin{array}{l}22 \\
15\end{array}$ \\
\hline Klebsiella spp. & 71 & $\begin{array}{l}\mathrm{C} 1 \\
\mathrm{C} 2\end{array}$ & & $\frac{1}{2}$ & $\begin{array}{l}18 \\
53\end{array}$ & $\begin{array}{l}46 \\
13\end{array}$ & 2 & 1 & $\begin{array}{l}3 \\
3\end{array}$ \\
\hline Escherichia coli & 68 & $\begin{array}{l}\mathrm{C} 1 \\
\mathrm{C} 2\end{array}$ & 1 & 2 & $\begin{array}{r}6 \\
28\end{array}$ & $\begin{array}{l}50 \\
26\end{array}$ & $\begin{array}{l}4 \\
5\end{array}$ & $\begin{array}{l}3 \\
1\end{array}$ & $\begin{array}{l}5 \\
5\end{array}$ \\
\hline Other enterobacteria ${ }^{*}$ & 31 & $\begin{array}{l}\mathrm{C} 1 \\
\mathrm{C} 2\end{array}$ & & & $\begin{array}{l}2 \\
3\end{array}$ & $\begin{array}{r}10 \\
6\end{array}$ & $\begin{array}{l}2 \\
6\end{array}$ & $\begin{array}{l}3 \\
1\end{array}$ & $\begin{array}{l}14 \\
15\end{array}$ \\
\hline $\begin{array}{c}\text { Haemophilus } \\
\text { influenzae }\end{array}$ & 38 & $\begin{array}{l}\mathrm{C} 1 \\
\mathrm{C} 2\end{array}$ & & & 4 & $\begin{array}{r}6 \\
18\end{array}$ & $\begin{array}{r}19 \\
7\end{array}$ & $\begin{array}{r}10 \\
7\end{array}$ & $\begin{array}{l}3 \\
2\end{array}$ \\
\hline
\end{tabular}

*These include Bacillus anitratus (7), Serratia marcescens (3), Providencia spp. (5), Enterobacter spp. (9), and atypical $E$. coli (7). lexin) and Eskacef and Velocef (both doctors and nurses in this regard and to cephradine).

We thank Mrs. J. Andrews, FILMT and Mr. K. Bedford, B.Sc., for technical assistance.
J. D. WILliams

East Birmingham Hospital

2 May.

May, J. R., and Ingold, A., British fournal of Diseases of the Chest, 1972, 66, 185.
Kosmidis, J., Williams fournal of Clinical Practice, 1972, 26, 341.

\section{Risks of the Good Samaritan}

SIR,-It is commonly asserted that doctors are reluctant to render emergency aid at the scene of an accident because they fear that they will be sued for malpractice in the event of an unfortunate outcome. It would seem that there is a widespread assumption that many malpractice actions have resulted from such circumstances.

It is gratifying to note that in its report the commission that was convened in the U.S.A. two years ago to examine the medical malpractice problem in that country has ex ploded this myth. The commission was aware of only one reported case in which an injured person filed a malpractice suit against a doctor in suoh circumstances and this was in Hawaii. Furthermore, the commission had no information about any out of court settlement of any action that arose out of a doctor rendering emergency treatment at the scene of an accident. The Medical Defence Union has never been involved in suah action.

Though the fears of doctors about their potential liability for rendering emergency aid may be real, they appear to be based on little more than rumour or hearsay, generated and perpetuated in large part by the mass media. The legal risks in rendering emergency aid to accident victims are infinitesimal and there is no factual basis for the commonly asserted belief that actions are likely to stem from rendering emergency aid at the scene of an accident. Publicity should be given to this fact in order to allay the fears of
Dudley Road Hospital,

A. M. GeDDES

Goodall, J. A. D., and Geddes, A. M., British encourage the rendering of emergency treatment at the scene of an accident.-I am, etc.,

PHILIP H. AdDISON

Medical Defence Union,

Londion W.1

Report of the Secretary's Commission on Medical Malpractice, Washington, U.S. Depar.
Health, Education and Welfare, 1973.

\section{Redesign of Medical Records in General Practice}

SIR,-The anxieties expressed by Drs. J. M. Brown, D. Jarratt, and H. C. I. Bywater (26 May, p. 483) in relation to the contents of ECN 946 are understandable, but in some respects wide of the mark. It is only fair to state that the Health Departments' acceptance of the recommendation that A4 size folders should be adopted for general practice records follows a resolution passed by the Conference of Local Medical Committees in $1971^{1}$ "that as a matter of policy the future medical record should be of a size to contain unfolded paper of A4 size. . ." This is the opinion of the elected representatives of the profession. It is reinforced by the findings of research involving a random sample of general practitioners in Scotland, ${ }^{2}$ where there was substantial support (especially among more recent graduates) for the concept of A4-sized folders, and also by the comments of practitioners involved in the experimental Wantage records project. ${ }^{3}$

Far from being inconvenient, the vast majority of doctors who have reported experience in the use of A4 folders have found this system to be a more versatile, more efficient, and more satisfactory clinical tool in patient care than the system it is designed to supersede. There are many reasons for this but one of the most important in this era of expanding communication is the simple one of the ease with which letters filed flat and in chronological order can be scanned and, when appropriate (and it is often appropriate), "weeded" to rid files of obsolete data, thus reducing bulk.

The problems of finding or making space for these larger record folders and for financing the exercise are recognized to be difficult ones, but the introduction of the system will be gradual and voluntary and the accumulated experience of practices which elect to convert their records should provide more accurate calculations on the basis of which negotiations will doubtless continue.

Your correspondents who believe that a records system designed in 1920 is adequate for the greatly changed medical scene of the 1970s are of course entitled to their opinion, but not to an unsubstantiated claim that they speak for a "silent majority." Meanwhile they should not seek to impede the voluntary introduction of a system which both theory and practice have shown to have considerable potential for increased efficiency and better patient care.-I am, etc.,

Edinburgh

\section{J. J. C. CORMaCK}

1 British Medical fournal Supplement, 1971, 3, 17 Use of Medical Records: General Practitioner's vices Studies No. 15 Edinburgh, Scottish Home and Health Department, 1971.

Oxford Regional Hospital Board, $O$ and $M$ productivity Services Unit, Evaluation of Wantage

** In Spring 1971 the General Medical Ser- 
vices Committee in its Annual Report to the Conference of Representatives of Local Medical Committees, circulated to all N.H.S. general practitioners, stated that it had been considering "for some time the design of medical records." It recommended to the conference that the future medical records should be "of a size to contain unfolded paper of A4 size and should be made available to those doctors who wish to use it." The conference approved the G.M.S. Committee's proposal on the condition "that a firm undertaking is given by the Department of Health to finance all consequent alterations to equipment and premises arising therefrom." The Department subsequently set up a joint working party-including representatives from the G.M.S. Committee-on the redesign of medical records and has accepted in principle the working party's recommendation that the A4 international paper size $(210 \mathrm{~mm} \times 297 \mathrm{~mm})$ should be used for general practitioners' record sheets (Supplement, 19 May, p. 53). In its annua report this year also sent to all N.H.S. general practitioners-the G.M.S. Committee stated that it understood that the Health Departments were prepared to allocate funds to make some of the new recond folders generally available to general practitioners some time in 1974. The committee commented that in the early stages of conversion the new size would be an alternative to the existing medical record envelope and that the two sizes would be in use during a transitional period of several years.-ED., B.M.f.

SIR,-The recent circular from the Department of Health (ECN 946) heralding the introduction of a new medical record for general practice is as welcome as it has been long delayed. The present medical record envelope is at best barely adequate and, if the current movement to raise the standard of general practice in this country is to continue, a much improved form of medical record is necessary.

An A4-size record will encourage a better standard of note-making and enable the doctor to refer at a glance to previous notes and letters. This is in marked contrast to the present envelope, which encourages cryptic and often indecipherable notes and from which any particular letter can be found only at the cost of several minutes' searching through tightly folded pieces of paper. Admittedly, there will be considerable problems in finding sufficient storage space in many practioes, but the potential advantages are so great that the short-term difficulties must not be allowed to stand in the way of a useful and necessary reform.-I am, etc.

Oxford

S. R. BURNE

\section{Ampicillin for Sore Throat}

SIR,-I enjoyed Dr. H. Pullen's article on infectious mononucleosis (12 May, p. 350) and share his concern about the occurrence of ampicillin rashes. My partners and I took part earlier this year in an exercise in which 143 sore throats were swabbed. Forty-nine, or over one-third, yielded swabs positive for Haemophilus species while 66 yielded swabs positive for haemolytic streptococcus. Thus penicillin was not the antibiotic of choice in over one-third of these patients.

Published evidence suggests that, on balance, morbidity is reduced by the exhibition of antibacterial drugs in acute sore throat. The choice of drug is governed by the usual considerations, and I think ampicillin must be considered one of the front runners.-I am, etc.,

\section{A. A. ROBERTSON}

West Granton Medical Group

Edinburgh

\section{Antibiotic Sensitivity of Klebsiella}

SIR,-In the interesting account by Dr. Eunice Lockey and others (19 May, p. 400) of a Klebsiella aerogenes blood infection from E.C.G. electrode pads one was surprised to read-“"On routine disc sensitivity testing the organism appeared sensitive to ampicillin ..."-though it is later stated that the minimum inhibitory concentration of this drug was $32 \mu \mathrm{g} / \mathrm{ml}$. Is it possible that the method or interpretation of their discplate test is in need of a little review? - I am, etc.,

\section{Department of Pathology, \\ Royal Berkshire Hospital,}

Reyal Ber

T. D. M. MARTIN

Thrombocytopenic Purpura and Haemolytic Anaemia after Influenza Vaccination

SIR,-Dr. R. C. Brown and his colleagues (5 May, p. 303) report thrombocytopenic purpura and haemolytic anaemia after inoculation against influenza. But why diagnose thrombotic thrombocytopenic purpura (T.T.P.)? Admittedly, an acute illness with thrombocytopenia, purpura, haemolytic anaemia, coma, and uraemia constitutes a syndrome that suggests T.T.P. (the only classic features of T.P.P. that were missing are fluctuating focal neurological signs and death). T.T.P.- a very rare disease (there are about 300 acceptable published cases) is the likeliest cause of an association of thrombocytopenia, purpura, and haemolytic anaemia; there are others, and different mechanisms may account for the haematological changes. The pathognomonic feature of T.T.P. is a distinctive form of thrombosis in arterioles and capillaries: without its unequivocal demonstration the diagnosis is only presumptive-in the case in question this histological proof was lacking.

When treatment is credited with cure of so fatal a disease, presumptively diagnosed, it is important that the diagnosis be recognized to be unproved, and therefore possibly incorrect. In contrast to other conditions with peripheral thrombocytopenia, T.T.P. is commonly associated with increased platelet production, though the increased output fails to keep up with consumption in the formation of the myriad platelet thrombi. The observation in the case under discussion that the megakaryocytes showed little platelet budding is not inconsistent with T.T.P., but it is contrary to what is usual. Similarly, it is relatively uncommon in T.P.P. to see the deformed red blood cells that were found in this case. Such less than typical findings reinforce the need for histological proof of a diagnosis of T.T.P.
Terminological ambiguity has led to confusion between T.T.P. (Moschcowitz's syndrome) and the less rare and prognostically quite different haemolytic-uraemic syndrome (H.U.S.). Both T.T.P. and H.U.S. are described as characterized by "microangiopathic haemolytic anaemia." In relation to H.U.S. this term indicates that the anaemia is due to damage to red cells during circulation through diseased small vessels (microangiopathy), particularly glomerular capillaries but oocasionally abnormal vessels in other conditions (angiolipomas, for instance, and some cases of T.T.P. itself). This usage differs from the sense of "thrombotic microangiopathic haemolytic anaemia," coined as a synonym for T.T.P. by an unseasoned pathologist $^{1}$ who thought T.T.P. an inadequate name because neither thrombocytopenia nor purpura is as frequent as haemolytic anaemia; to acknowledge the pathognomonic thrombosis in the smallest blood vessels he thought up the term "thrombotic microangiopathy"-the rest followed. If the terms "thrombotic microangiopathic haemolytic anaemia" (a synonym of T.T.P.) and "microangiopathic haemolytic anaemia" (the anaemia of H.U.S.) are compared, it may be recognized that in the latter "hasmolytic anaemia" is qualified by "microangiopathic" to indicate its vascular cause; in the former, "microangiopathic" is qualified by "thrombotic" (indicating that the microangiopathy is characterized by thrombosis) and the epithet "thrombotic microangiopathic" merely stresses that the anaemia is accompanied by the thrombotic microangiopathy.

T.T.P. and H.U.S. are not the same disease. Is it too late to make this point? Experience at the International Congress of Haematology last year was discouraging; the discussion after a presentation of 41 previously unrecorded cases of T.T.P. ${ }^{2}$ revealed an almost unanimous failure to distinguish between T.T.P. and H.U.S. - thus far have confused concepts and neoteric imprecision obscured the differences in pathology, manifestations, and prognosis. Disseminated intravascular platelet thrombosis is not a feature of H.U.S.; it is characteristic of T.T.P. H.U.S. is a serious but by no means regularly fatal disease; T.T.P. is fatal. Haemolysis and uraemia are essential features of H.U.S.; neither is invariably part of the syndrome of T.T.P.

Has any patient with histologically confirmed T.T.P. recovered?-I am, etc.,

Northwood, Middlesex

W. ST. C. SYMmers

Symmers, W. St. C., British Medical fournal, $1952,2,897$.

Symmers, W. St. C., Lectures, 14th International:
Congress of Hematology, Săo Paulo, 1972, p. 62.

Is Your Pain Really Necessary?

SIR,-One of the more distressing conditions experienced by women of childbearing and pre-childbearing age is spasmodic dysmenorrhoea (see leading article 12 May, p. 323). While seldom if ever permanently disabling, spasmodic dysmenorrhoea is extremely painful and can cause great distress to the patient and her immediate family. The patient who suffers from this condition frequently consults her G.P. to seek relief from the pain, but all too often, as the result of years of indoctrination during adolescence, 